\title{
Synthesis of 6-(2-Methoxynaphthyl)-2,3- dihydro-1,2,4-triazine-3-thione as a New Reagent for Spectrophotometric Determination of Copper
}

\author{
Maliheh Barazandeh Tehrani, Hutan Ghanbari, Effat Souri, \\ Fazel Shamsa, and Mohsen Amini \\ Department of Medicinal Chemistry, Faculty of Pharmacy and Pharmaceutical Science Research Center, \\ Tehran University of Medical Sciences, Tehran 1417614411, Iran \\ Correspondence should be addressed to Maliheh Barazandeh Tehrani; barazand@sina.tums.ac.ir
}

Received 5 September 2013; Accepted 6 December 2013; Published 4 February 2014

Academic Editor: Teizo Kitagawa

Copyright (C) 2014 Maliheh Barazandeh Tehrani et al. This is an open access article distributed under the Creative Commons Attribution License, which permits unrestricted use, distribution, and reproduction in any medium, provided the original work is properly cited.

\begin{abstract}
A simple, sensitive, accurate, and green spectrophotometric method for the determination of $\mathrm{Cu}(\mathrm{II})$ using newly synthesized reagent, 6-(2-methoxynaphthyl)-2,3-dihydro-1,2,4-triazine-3-thione (MNDTT), has been developed. MNDTT was synthesized based on the acylation of methoxy naphthalene and reaction of the product with amyl nitrite, which upon reaction with thiosemicarbazide yielded 6-(2-meyhoxynaphthyl)-2,3-dihydro-1,2,4-triazine-3-thione. MNDTT produces a dark red complex with copper in methanol according to the $1: 2$ stoichiometry. Beer's law was obeyed over the concentration range of $2.5-20 \mu \mathrm{g} / \mathrm{mL}$ with $r^{2}=0.992$. The limit of detection and limit of quantification were 0.33 and $1.10 \mu \mathrm{g} / \mathrm{mL}$, respectively. Within-day and betweenday precision values were less than $3.68 \%$. Finally, the method has been applied to a dental alloy (110-plus) successfully and the results were compared with atomic absorption method. The results showed that there was no significant difference between the two methods $(P>0.05)$
\end{abstract}

\section{Introduction}

Copper is an essential micronutrient for many vital processes. Copper is present in a large number of enzymes, which are involved in electron transfer, activation of oxygen, and other small molecules as well as superoxide dismutation $[1,2]$. It serves as an essential cofactor for a variety of proteins involved in neurotransmitter synthesis as well as in neuroprotection via the $\mathrm{Cu} / \mathrm{Zn}$ superoxide dismutase. Copper in excess is toxic while $\mathrm{Cu}$ deficiency can lead to serious disease [3-5]. Copper ions have also showed antimicrobial activity against a wide range of microorganisms [6-8].

The determination of trace amounts of copper, because of its importance in health, medical, and industrial processes, is of great interest to analytical chemists. There are many reported methods for the determination of copper. The most common techniques are ICP-MS $[9,10]$, atomic absorption [11, 12], capillary electrophoresis [13], and UV/VIS spectrophotometry [14-16]. Most of these methods are time consuming or require expensive and complicated instruments. In addition, some methods use organic solvents such as chloroform or acetonitrile which are for the issue of environmental concern or worldwide storage crisis.

Among these techniques, visible absorption spectrophotometry represents the most convenient technique because of the availability of the instrumentation, simplicity, speed, precision, accuracy, and low cost. As it was conducted in our previous studies, 6-naphthyl and anthracenyl substituted, 1,2,4-triazine-3-thione form colored complexes with $\mathrm{Cu}(\mathrm{II})$ in basic media [17-20]. In this investigation the synthesis of 6-(2-methoxynaphthyl)-2,3-dihydro-1,2,4-triazine3 -thione has been synthesized as a chromogenic reagent for the determination of $\mathrm{Cu}(\mathrm{II})$ and validation of the developed method is reported. 


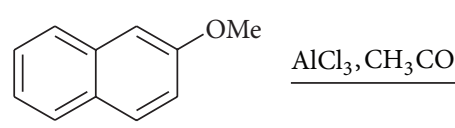

(I)<smiles>COc1ccc2cc(C(C)=O)ccc2c1</smiles>

(II)

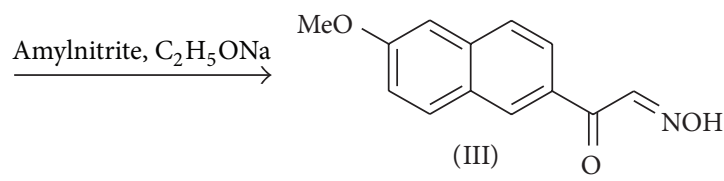

(III)<smiles>COc1ccc2cc(C(=O)C=NO)ccc2c1</smiles>

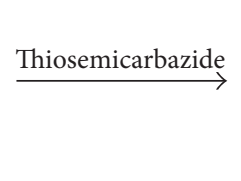<smiles>COc1ccc2cc(-c3cnc(=S)[nH]n3)ccc2c1</smiles>

FIGURE 1: Synthesis of 6-(2-methoxynaphthyl)-2,3-dihydro-1,2,4-triazine-3-thione (MNDTT).

\section{Experimental}

2.1. Apparatus. All spectra recordings and absorbance measurements were carried out on a Shimadzu, 160A UV/VIS spectrophotometer. Atomic absorption (AA Varian 220) was used for $\mathrm{Cu}$ determination in real samples. NMR spectra were recorded on a Bruker FT-500 Spectrometer (Bruker, Rheinstetten, Germany) with tetramethyl silane (TMS) as internal standard. Infrared spectra were obtained using a Perkin-Elmer Model 781 spectrograph. Mass spectra were taken using a Finnigan TSQ Spectrometer at $70 \mathrm{eV}$.

2.2. Reagents. 2-Methoxynaphthalene, thiosemicarbazide, amylnitrite, aluminium chloride, and acetyl chloride were used for ligand synthesis and were purchased from Fluka (Switzerland) or Merck Chemical Companies. Solvents (acetone, acetonitrile, ethyl alcohol, and methanol) were of HPLC grade and prepared from Merck (Germany).

Copper Nitrate Solution. A stock standard solution of $1 \mathrm{mg} / \mathrm{mL}$ $\mathrm{Cu}(\mathrm{II})$ was prepared by dissolving $0.5 \mathrm{~g}$ pure elemental copper in hot concentrated $\mathrm{HNO}_{3}$, cooling, and adjusting the volume to $500 \mathrm{~mL}$ by addition of the distilled water. Working solutions were prepared by proper dilution by ethyl alcohol.

Synthesis of the Chromogenic Reagent, MNDTT. The reagent 6-(2-methoxynaphthyl)-2,3-dihydro-1,2,4-triazine-3-thione (MNDTT) was synthesized according to Figure 1.

Synthesis of 2-Methoxy Acetyl Naphthalene (II). Acetyl chloride $(0.4 \mathrm{~g})$ and $\mathrm{AlCl}_{3}(0.67 \mathrm{~g})$ were mixed in a mortar in dry condition and then 2-methoxynaphthalen (I) $(0.5 \mathrm{~g})$ was added and mixed in oxygen protected condition. After $45 \mathrm{~min}$ cool water was added and the solution washed with ether. The product was extracted with ether and washed with hydrochloric acid and dried. The product was re-crystallized from ethanol-water to yield $0.454 \mathrm{~g}$ (72\%), Mp. $108-110^{\circ} \mathrm{C}$.

${ }^{13} \mathrm{C} \mathrm{NMR}\left(125 \mathrm{MHz}, \mathrm{CDCl}_{3}\right)$ was $32.68\left(\mathrm{CH}_{3} \mathrm{CO}\right), 55.36$ $\left(\mathrm{OCH}_{3}\right), 112.71,123.58,124.05,128.65,128.13,128.78,130.37$, $131.44,133.31,153.91$, and 205.22.

Synthesis of 6-(2-Methoxynaphthyl)-2,3-dihydro-1,2,4-triazine-3-thione (MNDTT)(IV). The resultant dried precipitate (II) was then refluxed with amyl nitrite in ethanol in presence of sodium ethoxide for $48 \mathrm{~h}$ in dry condition. The product (III), 2-methoxynaphthylglyoxal aldoxime, was then extracted with diethyl ether, dried, and crystallized from water-ethanol. The reaction product (III) and thiosemicarbazide were refluxed for $3 \mathrm{~h}$ in dilute hydrochloric acid. The progress of the reaction was monitored by TLC using a mixture of chloroform and methanol as a mobile phase. The reaction mixture was then cooled and filtered off. The precipitate was washed with ether and crystallized from DMSO$\mathrm{H}_{2} \mathrm{O}$. Compound (IV) was obtained as yellowish brown powder in $58 \%$ yield. ${ }^{13} \mathrm{C}$ NMR (125 MHz, DMSO) was 57.04 $\left(\mathrm{OCH}_{3}\right), 114.25,123.56,124.45,128.03,128.56,131.21,131.26$, $132.48,154.85,158.53,173.76$, and 188.74. ${ }^{1} \mathrm{H} \mathrm{NMR}(500 \mathrm{MHz}$, DMSO) was $3.87\left(\mathrm{~s}, 3 \mathrm{H}, \mathrm{CH}_{3}\right), 7.38-7.56(\mathrm{~m}, 3 \mathrm{H}), 7.57-7.62(\mathrm{~m}$, $2 \mathrm{H}), 810$ (s, $1 \mathrm{H})$, and 833 (bs, $1 \mathrm{H}, \mathrm{NH})$. Mass $m / z$ (\%) was 269 (7), 241 (5), 239 (20), 165 (10), 153 (20), 151 (100), and 138 (4).

General Procedure for Determination of $\mathrm{Cu}(\mathrm{II})$. In a series of $5 \mathrm{~mL}$ volumetric flask, $1 \mathrm{~mL}(2.5-20 \mu \mathrm{g} / \mathrm{mL})$ of $\mathrm{Cu}(\mathrm{II})$ and $2 \mathrm{~mL}$ of MNDTT $(0.002 \mathrm{M})$ were taken and the volume was adjusted to $5 \mathrm{~mL}$ with methanol. The absorbance of the solutions was recorded against reagent blank at $475 \mathrm{~nm}$ in a $1 \mathrm{~cm}$ quartz cell.

Analytical Application. $40 \mathrm{mg}$ of an amalgam (110-plus) containing $\operatorname{Ag}(\mathrm{I})(45 \%), \mathrm{Sn}(\mathrm{II})(30 \%)$, and $\mathrm{Cu}(\mathrm{II})(25 \%)$ was taken in a $50 \mathrm{~mL}$ beaker and $10 \mathrm{~mL} \mathrm{HNO}_{3}: \mathrm{HCl}(1: 1, \mathrm{v} / \mathrm{v})$ solution was added. The mixture was heated at $120^{\circ} \mathrm{C}$ for $30 \mathrm{~min}$ until the dissolution is completed and the resulting solution reaches minimum volume. The solution cooled and transferred to a $100 \mathrm{~mL}$ volumetric flask and diluted to mark with double distilled water. The copper content of the sample was analyzed according to the proposed method.

\section{Results and Discussion}

The reagent 6-(2-methoxynaphthyl)-2,3-dihydro-1,2,4-triazine-3-thione (MNDTT) was synthesized, due to our recent studies for preparing more sensitive chromogenic reagents, for determination of trace amount of some cations such as $\mathrm{Cu}(\mathrm{II}), \mathrm{Ni}(\mathrm{II})$, and $\mathrm{Hg}(\mathrm{II})$. To achieve more sensitivity, complexing moiety, 1,2,4-triazine-3-thione ring, was left intact and the chromogenic part was changed. MNDTT forms a brownish-red complex with $\mathrm{Cu}$ (II) in methanol. 
TABLE 1: Effect of the solvent system on the absorbance value of $\mathrm{Cu}(\mathrm{II})-\mathrm{MNDTT}$ complex $(20 \mu \mathrm{g} \mathrm{Cu}(\mathrm{II}) / \mathrm{mL})$.

\begin{tabular}{lcccc}
\hline Solvent & $0.1 \mathrm{M} \mathrm{NaOH}$ & Acetonitrile & Methanol & Ethanol \\
\hline$\lambda_{\max }$ & 476 & 482 & 475 & 479 \\
Absorbance & 0.05 & 0.108 & 0176 & 0143 \\
\hline
\end{tabular}

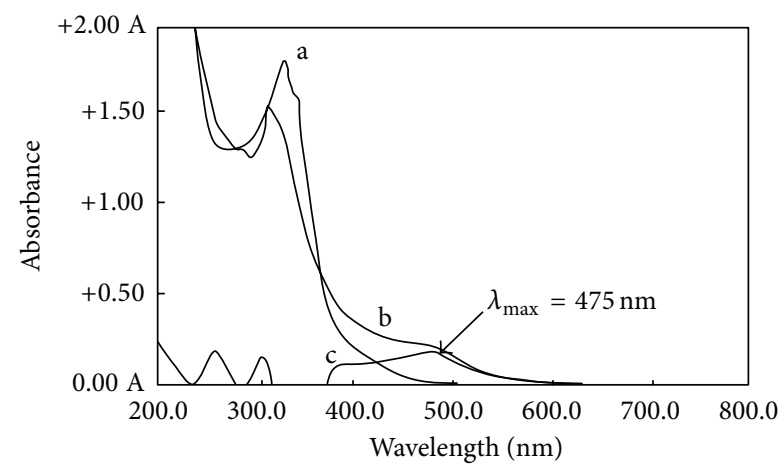

FIGURE 2: UV-VIS absorption spectra of (a) MNDTT, (b) $\mathrm{Cu}$ MNDTT complex, and (c) Cu-MNDTT complex against reagent $\operatorname{blank}\left(\lambda_{\max }=475 \mathrm{~nm}\right)$.

Different solvent systems (acetonitrile, water, $0.1 \mathrm{M}$ $\mathrm{NaOH}$, chloroform, ethanol, and methanol) were examined to find out more suitable solubility, better absorption spectra, and greener solvent. The results showed that the reagent, MNDTT, was not soluble in chloroform and water. Both the reagent and $\mathrm{Cu}-\mathrm{MNDTT}$ complex were soluble in $0.1 \mathrm{M}$ $\mathrm{NaOH}$, acetonitrile, ethanol, and methanol. The absorbance value was very low in basic media. Acetonitrile not only had lower sensitivity but also was not considered as an environmental and health friendly solvent $[25,26]$. Eventually, comparison of the absorption value of $\mathrm{Cu}-\mathrm{MNDTT}$ complex in methanolic and ethanolic media showed that the most suitable solvent for both reagent and complex was methanol (Table 1). Therefore, methanol which had greater absorbance value and was also considered as one of the greener solvents was selected for subsequent experiments.

Absorption Spectra. 6-(2-Methoxynaphthyl)-2,3-dihydro1,2,4-triazine-3-thion, which is synthesized as a new reagent, reacts with $\mathrm{Cu}(\mathrm{II})$ forming a red-colored complex in methanol. The absorption spectra of Cu-MNDTT complex versus the blank and the ligand (MNDTT) in methanol was recorded in the wavelength region of 200-800 nm (Figure 2). The ligand shows a maximum wavelength at $346 \mathrm{~nm}$ while the spectrum of $\mathrm{Cu}-\mathrm{MNDTT}$ reveals a maximum at $475 \mathrm{~nm}$ which increased as a function of $\mathrm{Cu} / \mathrm{MNDTT}$ molar ratio according to the curve reported in Figure 3.

Effect of $p H$. The influence of $\mathrm{pH}$ on the complex formation using Britton-Robinson buffer $(\mathrm{pH}=5-12)$ and $1 \mathrm{M} \mathrm{NaOH}$ was studied by measuring the real absorbance of the solution containing $\mathrm{Cu}(\mathrm{II})(20 \mu \mathrm{g} / \mathrm{mL})$ in the presence of the reagent MNDTT against the reagent blank. The results illustrated in Figure 4 reveal that maximum absorbance of the colored

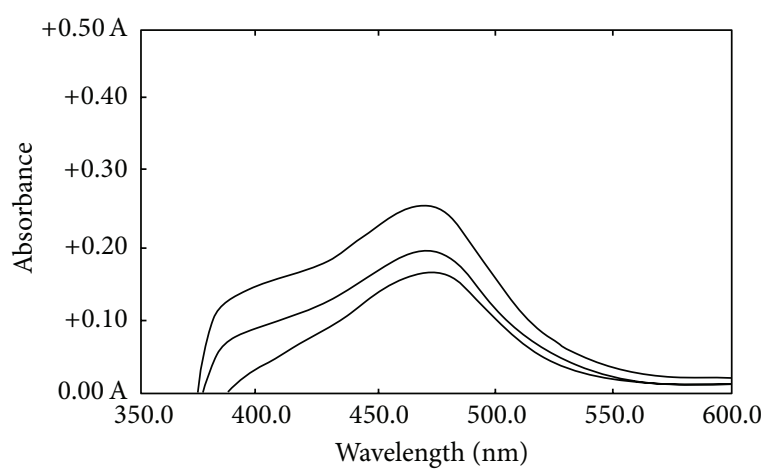

Figure 3: Absorption spectra of $\mathrm{Cu}-\mathrm{MNDTT}$ complex in three concentrations, $15,17.5$, and $20 \mu \mathrm{g} / \mathrm{mL}$.

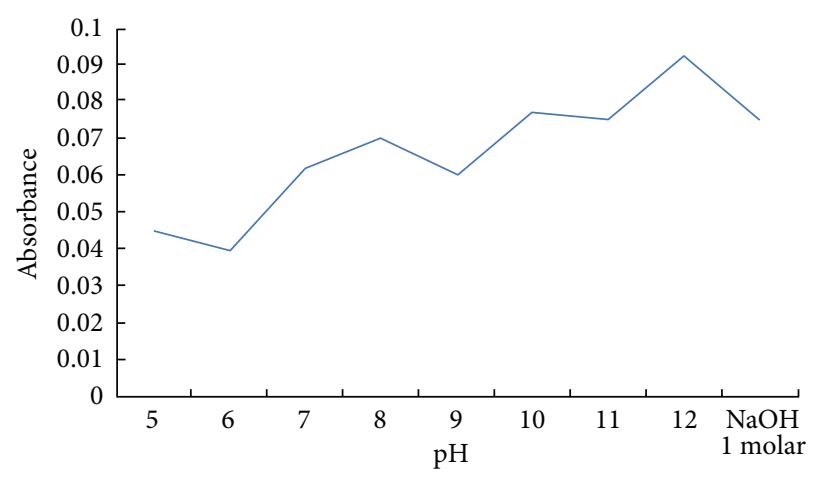

FIGURE 4: Influence of $\mathrm{pH}$ on the absorbance of $\mathrm{Cu}-\mathrm{MNDTT}$ complex.

complex was obtained at $\mathrm{pH}=12$. Comparing the results obtained in the absence of buffer (Table 1) with the above values reveals that the absorbance of the produced complex decreased in the presence of aqua buffer solution. Thus, in the subsequent work, no buffer was added.

Effect of Surfactant. The effect of cationic (cetrimide), anionic (sodium lauryl sulfate), and nonionic (tween 80) surfactants was studied and results showed that surfactants caused turbidity in solution in different surfactant concentrations. Therefore, this method has been used in the absence of surfactants.

Stability of Complex. To study the stability of Cu-MNDTT complex, the absorbance of a $25 \mu \mathrm{g} / \mathrm{mL}$ solution of $\mathrm{Cu}$ (II) at the optimum condition was recorded over a period of $3 \mathrm{~h}$ with an interval of $30 \mathrm{~min}$, after 24 and 48 hours. The results showed that the complex was completely stable for at least 3 hours and there were no significant changes $(<3 \%)$ in the absorbance of the complex after 24 hours.

Stoichiometry of the Complex. The chemical structure of $\mathrm{Cu}-\mathrm{MNDTT}$ complex was determined by limiting logarithmic method. As it is shown in Figure 5 the logarithm of absorbance intensities of $\mathrm{Cu}$-MNDTT complex versus $\left.\log [\mathrm{Cu}] 1.57 \times 10^{-5}-4.68 \times 10^{-5} \mathrm{M}\right)$ at fixed concentration of 


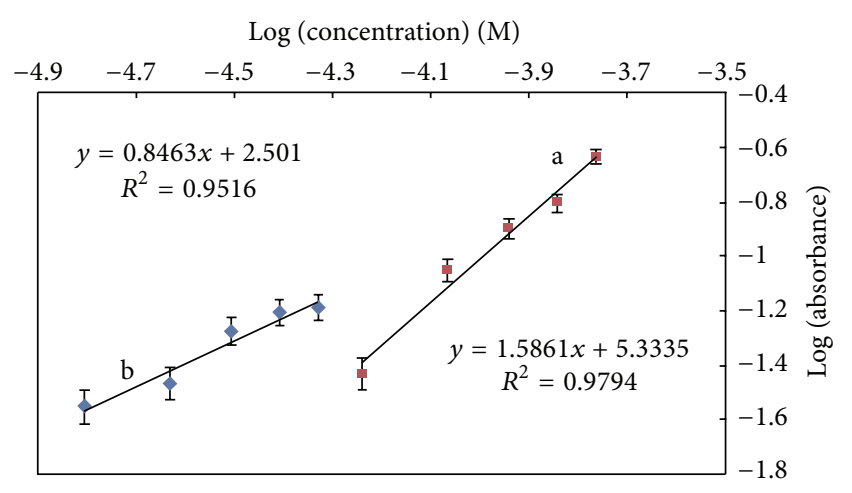

FIGURE 5: Limiting logarithmic plot for ratio of $\mathrm{Cu}(\mathrm{II})$ and reagent (MNDTT); (a) $\log$ abs versus $\log [$ MNDTT] and (b) log abs versus $\log [\mathrm{Cu}]$.

$\operatorname{MNDTT}\left(5.58 \times 10^{-5} \mathrm{M}\right)$ and $\log [\mathrm{MNDTT}]\left(5.75 \times 10^{-5}-\right.$ $\left.1.72 \times 10^{-4} \mathrm{M}\right)$ at fixed concentration of $\mathrm{Cu}(\mathrm{II})\left(1.57 \times 10^{-5} \mathrm{M}\right)$ were plotted. The values of the slopes of these lines were 0.8463 and 1.586 , confirming the $1: 2$ ratios for the complex formation reaction.

\section{Validation of the Method}

Linearity, $L O D$, and $L O Q$. The opposed method was calibrated using 6 series in the range of $2.5-20 \mu \mathrm{g} / \mathrm{mL}$. The analytical parameters of the proposed method are given in Table 2. The detection limit ( $3 \mathrm{SD} / K$ ) and quantification limit $(10 \mathrm{SD} / K$ ) (where SD is the standard deviation of the $y$ intercept and $K$ represents the slope of the straight line), as defined by IUPAC, were found to be 0.33 and $1.10 \mu \mathrm{g} / \mathrm{mL}$, respectively [27].

Precision and Accuracy. The accuracy and precision of the proposed method were determined at three different concentrations within the same day $(n=3)$ and over three different days $(n=9)$. Percentage relative standard deviation (RSD\%) as precision and percentage relative error (Er\%), which shows accuracy of the suggested method, was less than $3.68 \%$ and $2.40 \%$, respectively. This indicates good accuracy and precision of the method (Table 3 ).

Study of Interferences. The effect of diverse ions was determined using a standard solution containing $20 \mu \mathrm{g} / \mathrm{mL}$ of $\mathrm{Cu}(\mathrm{II})$ and $20 \mu \mathrm{g} / \mathrm{mL}$ of the studied ions. The method was completed according to the general procedure and the absorbance value was obtained against the reagent blank at $475 \mathrm{~nm}$. Similar to the results obtained for the naphthyl derivative of 1,2,4-triasine-3-thione (6-(2-naphthyl)-2,3dihydro-1,2,4-triasine-3-thione) obtained in previous study, the new reagent had no interference with $\mathrm{Fe}(\mathrm{II}), \mathrm{Ba}(\mathrm{II})$, $\mathrm{Mg}(\mathrm{II}), \mathrm{Ca}(\mathrm{II}), \mathrm{Cd}(\mathrm{II}), \mathrm{Co}(\mathrm{II}), \mathrm{Mn}(\mathrm{II})$, and $\mathrm{Sr}(\mathrm{II}) . \mathrm{Ni}(\mathrm{II})$, $\mathrm{Hg}(\mathrm{II})$, and $\mathrm{Pd}(\mathrm{II})$ ions form complexes with MNDTT which have maximum absorbance between 400 and $500 \mathrm{~nm}$ [17]. As there was no suitable masking agent for these ions, derivative
TABLE 2: Analytical parameters of calibration curves of copper (II)reagent $(n=9)$.

\begin{tabular}{lc}
\hline Parameters & \\
\hline Linearity & $2.50-20.00 \mu \mathrm{g} / \mathrm{mL}$ \\
Limit of detection & $0.33 \mu \mathrm{g} / \mathrm{mL}$ \\
Limit of quantification & $1.10 \mu \mathrm{g} / \mathrm{mL}$ \\
Molar absorptivity & 4350.5 \\
Regression equation & $Y=0.01286 x+0.01213$ \\
SD of slope & $8.66 \times 10^{-5}$ \\
RSD of slope & 0.57 \\
SD of intercept & $3.60 \times 10^{-4}$ \\
Coefficient correlation & 0.992 \\
\hline
\end{tabular}

TABLE 3: Accuracy and precision data for determination of copper in one day $(n=3)$ and three subsequent days $(n=9)$.

\begin{tabular}{lccc}
\hline Added $(\mu \mathrm{g} / \mathrm{mL})$ & Found $(\mu \mathrm{g} / \mathrm{mL})$ & CV\% & Error\% \\
\hline Within-day $(n=3)$ & & & \\
5.00 & $4.88 \pm 0.14$ & 2.87 & -2.40 \\
10.00 & $10.14 \pm 0.13$ & 1.28 & 1.40 \\
17.50 & $17.43 \pm 0.06$ & 0.34 & -0.40 \\
Between-day $(n=9)$ & & & \\
5.00 & $4.89 \pm 0.18$ & 3.68 & -2.20 \\
10.00 & $10.17 \pm 0.13$ & 1.28 & 1.70 \\
17.50 & $17.36 \pm 0.11$ & 0.63 & -0.80 \\
\hline
\end{tabular}

spectrophotometric method has been recommended for analyzing $\mathrm{Cu}(\mathrm{II})$ in the presence of $\mathrm{Ni}, \mathrm{Hg}$, or Pd ions.

Application of the Method to Real Sample. In order to evaluate the analytical applicability of the proposed method, it was applied for the determination of $\mathrm{Cu}$ (II) in a dental amalgam 110-plus. The proposed method was compared with the atomic absorption method. The results and recoveries presented in Table 4 indicate the percentage of recovery 97.5 and 96.5 for spectrophotometry and atomic absorption method, respectively. Using the two-tailed $t$-test and $f$-test methods, it was revealed that there was no significant difference between the results obtained from these two methods ( $P$ value $>0.05$ ).

Relative Recovery. The relative recovery was determined using the standard addition method $(n=3)$. The percent relative recovery of $101.66 \pm 1.24$ indicates that no interference with other components in amalgam has been observed.

\section{Conclusion}

A simple, rapid, sensitive, and accurate method for determination of $\mathrm{Cu}$ (II) using the newly synthesized reagent, 6-(2methoxynaphthyl)-2,3-dihydro-1,2,4-triazine-3-thion, was developed. The proposed method gave a low LOD and a good RSD. Comparison of characteristic features of some spectrophotometric methods reported earlier for the determination of copper reveals the suitability of the present work in terms of molar absorptivity, linear range, interferences, LOD, and so 
TABLE 4: Application of the proposed method to the determination of $\mathrm{Cu}(\mathrm{II})$ in amalgam $(n=3)$.

\begin{tabular}{|c|c|c|c|c|c|}
\hline \multirow{2}{*}{ Compound } & \multirow{2}{*}{ Label claimed (mg) } & \multicolumn{2}{|c|}{ Found (mean $\pm \mathrm{sd})$} & \multicolumn{2}{|c|}{ Statistical tests* } \\
\hline & & Proposed method & A. A. method & & \\
\hline 110-plus & 10.00 & $9.75 \pm 0.07$ & $9.66 \pm 0.10$ & $t=0.265$ & $F=0.647$ \\
\hline
\end{tabular}

TABLE 5: Comparison of reagents for the spectrophotometric determination of copper (II).

\begin{tabular}{|c|c|c|c|c|c|c|}
\hline Reagent & $\begin{array}{c}\text { Molar } \\
\text { absorptivity }\end{array}$ & $\lambda_{\max }(\mathrm{nm})$ & Linear range & Extractant & LOD & Reference \\
\hline Chloro-(phenyl)glyoxime & $8 \times 10^{3}$ & 290.5 & $0.1-10(\mu \mathrm{g} / \mathrm{mL})$ & - & $0.01(\mu \mathrm{g} / \mathrm{mL})$ & [21] \\
\hline $\begin{array}{l}\text { 1-Phenyl-1,2-propanedione- } \\
\text { 2-oxime } \\
\text { thiosemicarbazone }\end{array}$ & $5.5 \times 10^{3}$ & 465 & $0.35-7.63(\mu \mathrm{g} / \mathrm{mL})$ & - & - & {$[22]$} \\
\hline NDTT & - & 501 & $1-30(\mu \mathrm{g} / \mathrm{mL})$ & Chloroform & $0.26(\mu \mathrm{g} / \mathrm{mL})$ & {$[18]$} \\
\hline meso-HMPAO & 338 & 497 & $0.5-370(\mu \mathrm{g} / \mathrm{mL})$ & - & $0.50(\mu \mathrm{g} / \mathrm{mL})$ & {$[23]$} \\
\hline HMBO & $7 \times 10^{2}$ & 400 & $0-31.75(\mu \mathrm{g} / 10 \mathrm{~mL})$ & Chloroform & - & {$[24]$} \\
\hline MNDTT & $4.4 \times 10^{3}$ & 475 & $2.5-20(\mu \mathrm{g} / 10 \mathrm{~mL})$ & - & $0.33(\mu \mathrm{g} / 10 \mathrm{~mL})$ & Present method \\
\hline
\end{tabular}

forth (Table 5). The use of MNDTT as a complexing reagent was utilized for nonextractive determination of $\mathrm{Cu}$ (II) in dental amalgam. The results were in good agreement with the atomic absorption method. Additionally, the method was much safer, since only a small amount of methanol was used which is considered as "green chemistry" for determination process. Therefore, the proposed method can be recommended for pharmaceutical and industrial samples.

\section{Conflict of Interests}

The authors declare that there is no conflict of interests regarding the publication of this paper.

\section{Acknowledgments}

This study was part of an M.D. thesis/dissertation supported by Tehran University of Medical Sciences and Pharmaceutical Sciences Research Center.

\section{References}

[1] L. Q. Hatcher and K. D. Karlin, "Oxidant types in copperdioxygen chemistry: the ligand coordination defines the $\mathrm{Cu}_{n}$ $\mathrm{O}_{2}$ structure and subsequent reactivity," Journal of Biological Inorganic Chemistry, vol. 9, no. 6, pp. 669-683, 2004.

[2] A. C. Rosenzweig and M. H. Sazinsky, "Structural insights into dioxygen-activating copper enzymes," Current Opinion in Structural Biology, vol. 16, no. 6, pp. 729-735, 2006.

[3] Y.-M. Kuo, B. Zhou, D. Cosco, and J. Gitschier, "The copper transporter CTR1 provides an essential function in mammalian embryonic development," Proceedings of the National Academy of Sciences of the United States of America, vol. 98, no. 12, pp. 6836-6841, 2001.

[4] R. R. Crichton, Biological Inorganic Chemistry: A New Introduction to Molecular Structure and Function, Elsevier, Amsterdam, The Netherland, 2nd edition, 2012.
[5] D. Strausak, J. F. B. Mercer, H. H. Dieter, W. Stremmel, and G. Multhaup, "Copper in disorders with neurological symptoms: Alzheimer's, Menkes, and Wilson diseases," Brain Research Bulletin, vol. 55, no. 2, pp. 175-185, 2001.

[6] R. Gyawali, S. A. Ibrahim, S. A. Abu Hasfa, S. Q. Smqadri, and Y. Haik, "Antimicrobial activity of copper alone and in combination with lactic acid against Escherichia coli O157:H7 in laboratory medium and on the surface of lettuce and tomatoes," Journal of Pathogens, vol. 2011, Article ID 650968, 9 pages, 2011.

[7] I. Codiță, D. M. Caplan, E. C. Drăgulescu et al., "Antimicrobial activity of copper and silver Nano films on nosocomial bacterial species," Roumanian Archives of Microbiology and Immunology, vol. 69, no. 4, pp. 204-212, 2010.

[8] L. Zhu, J. Elguindi, C. Rensing, and S. Ravishankar, "Antimicrobial activity of different copper alloy surfaces against copper resistant and sensitive Salmonella enterica," Food Microbiology, vol. 30, no. 1, pp. 303-310, 2012.

[9] Y. Zhu, K. Inagaki, and K. Chiba, "Determination of $\mathrm{Fe}, \mathrm{Cu}, \mathrm{Ni}$, and $\mathrm{Zn}$ in seawater by ID-ICP-MS after preconcentration using a syringe-driven chelating column," Journal of Analytical Atomic Spectrometry, vol. 24, no. 9, pp. 1179-1183, 2009.

[10] V. Chrastný and M. Komárek, "Copper determination using ICP-MS with hexapole collision cell," Chemical Papers, vol. 63, no. 5, pp. 512-519, 2009.

[11] M. Ghaedi, F. Ahmadi, and A. Shokrollahi, "Simultaneous preconcentration and determination of copper, nickel, cobalt and lead ions content by flame atomic absorption spectrometry," Journal of Hazardous Materials, vol. 142, no. 1-2, pp. 272-278, 2007.

[12] S. Soriano, A. D. P. Netto, and R. J. Cassella, "Determination of $\mathrm{Cu}, \mathrm{Fe}, \mathrm{Mn}$ and $\mathrm{Zn}$ by flame atomic absorption spectrometry in multivitamin/multimineral dosage forms or tablets after an acidic extraction," Journal of Pharmaceutical and Biomedical Analysis, vol. 43, no. 1, pp. 304-310, 2007.

[13] J. Threeprom, W. Som-Aum, and J.-M. Lin, "Determination of $\mathrm{Pb}(\mathrm{II}), \mathrm{Cu}(\mathrm{II})$ and $\mathrm{Fe}(\mathrm{III})$ with capillary electrophoresis using ethylenediaminetetraacetic acid as a complexing agent and vancomycin as a complex selector," Analytical Sciences, vol. 22, no. 9, pp. 1179-1184, 2006. 
[14] J. Škrlíková, V. Andruch, I. S. Balogh, L. Kocúrová, L. Nagy, and Y. Bazel', "A novel environmentally friendly dispersive liquidliquid micro extraction procedure for the determination of copper," Microchemical Journal, vol. 99, pp. 40-45, 2011.

[15] D. Fu and D. Yuan, "Spectrophotometric determination of trace copper in water samples with thiomichlersketone," Spectrochimica Acta A, vol. 66, no. 2, pp. 434-437, 2007.

[16] J. Karthikeyan, P. P. Naik, and A. Nityananda Shetty, "A rapid extractive spectrophotometric determination of copper(II) in environmental samples, alloys, complexes and pharmaceutical samples using 4-N,N(dimethyl)amino]benzaldehyde thiosemicarbazone," Environmental Monitoring and Assessment, vol. 176, no. 1-4, pp. 419-426, 2011.

[17] F. Shamsa and M. Barazandeh-Tehrani, "Synthesis of 6(2-naphthyl)-2,3-dihydro-as-triazine-3-thione as a sensitive reagent for the spectrophotometric determination of $\mathrm{Cu}$ (II)," Daru, vol. 12, no. 2, pp. 76-80, 2004.

[18] M. B. Tehrani and E. Souri, "Third derivative spectrophotometric method for simultaneous determination of copper and nickel using 6-(2-naphthyl)-2, 3-dihydro-1,2,4-triazine-3thione," E-Journal of Chemistry, vol. 8, no. 2, pp. 587-590, 2011.

[19] M. B. Tehrani, S. F. Shamsa, S. Shams, and M. M. Farahani, "Spectrophotometric determination of copper in serum using 6-(2-naphthyl)-2,3-dihydro-1,2,4-triazine-3-thione," Asian Journal of Chemistry, vol. 22, no. 1, pp. 21-26, 2010.

[20] M. Barazandeh Tehrani, S. M. S. Mirkamali, E. Souri, and A. Foroumadi, "Derivative spectrophotometric method for simultaneous determination of nickel (II) and copper (II) using 6-(Anthracen-2-yl)-2,3-dihydro-1,2,4-triazine-3-thione," Asian Journal of Chemistry, vol. 24, no. 10, pp. 4517-4521, 2012.

[21] O. Turkoglu and M. Soylak, "Spectrophotometric determination of copper in natural waters and pharmaceutical samples with Chloro(phenyl) glyoxime," Journal of the Chinese Chemical Society, vol. 52, no. 3, pp. 575-579, 2005.

[22] K. Hussain Reddy, N. B. L. Prasad, and T. Sreenivasulu Reddy, "Analytical properties of 1-phenyl-1,2-propanedione-2-oxime thiosemicarbazone: simultaneous spectrophotometric determination of copper(II) and nickel(II) in edible oils and seeds," Talanta, vol. 59, no. 3, pp. 425-433, 2003.

[23] K. Thipyapong and C. Suksai, "Spectrophotometric determination of copper (II) using diamine-dioxime derivative," Bulletin of the Korean Chemical Society, vol. 24, no. 12, pp. 1767-1770, 2003.

[24] M. K. Pourohit and K. K. Desai, "2-Hydroxy-4-methoxybenzophenone oxime as an analytical reagent for Copper(II)," E-Journal of Chemistry, vol. 2, no. 2, pp. 161-164, 2005.

[25] C. Capello, U. Fischer, and K. Hungerbühler, "What is a green solvent? A comprehensive framework for the environmental assessment of solvents," Green Chemistry, vol. 9, no. 9, pp. 927934, 2007.

[26] K. Alfonsi, J. Colberg, P. J. Dunn et al., "Green chemistry tools to influence a medicinal chemistry and research chemistry based organisation," Green Chemistry, vol. 10, no. 1, pp. 31-36, 2008.

[27] A. Shrivastava, B. Vipin, and R. Gupta, "Methods for the determination of limit of detection and limit of quantification of analytical methods," Chronicles of Young Scientists, vol. 2, no. 1, pp. 21-25, 2011. 

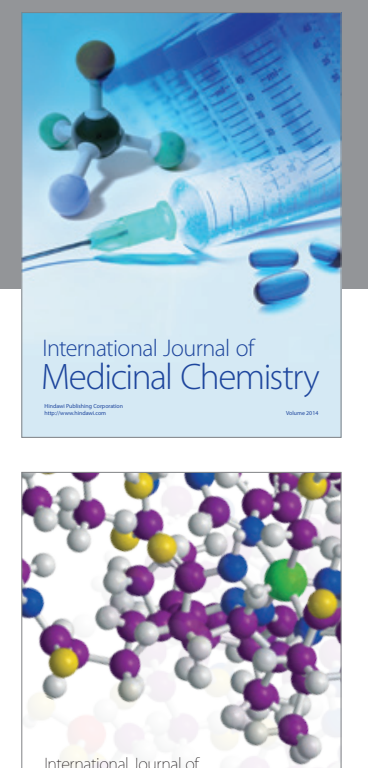

\section{Carbohydrate} Chemistry

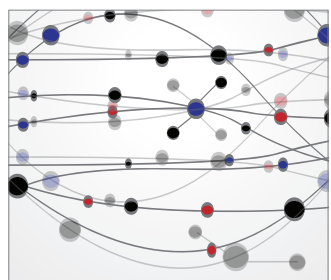

The Scientific World Journal
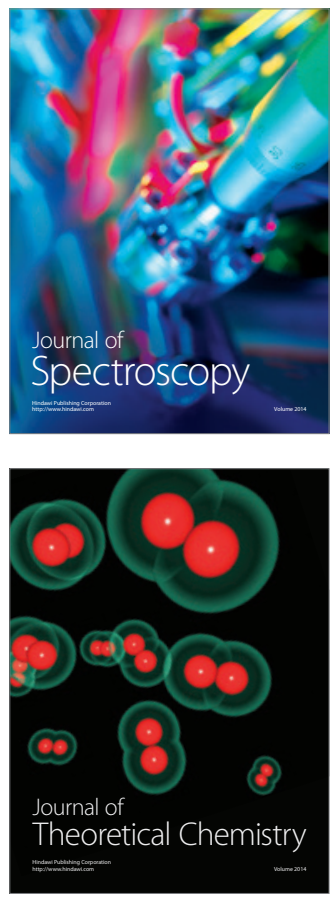
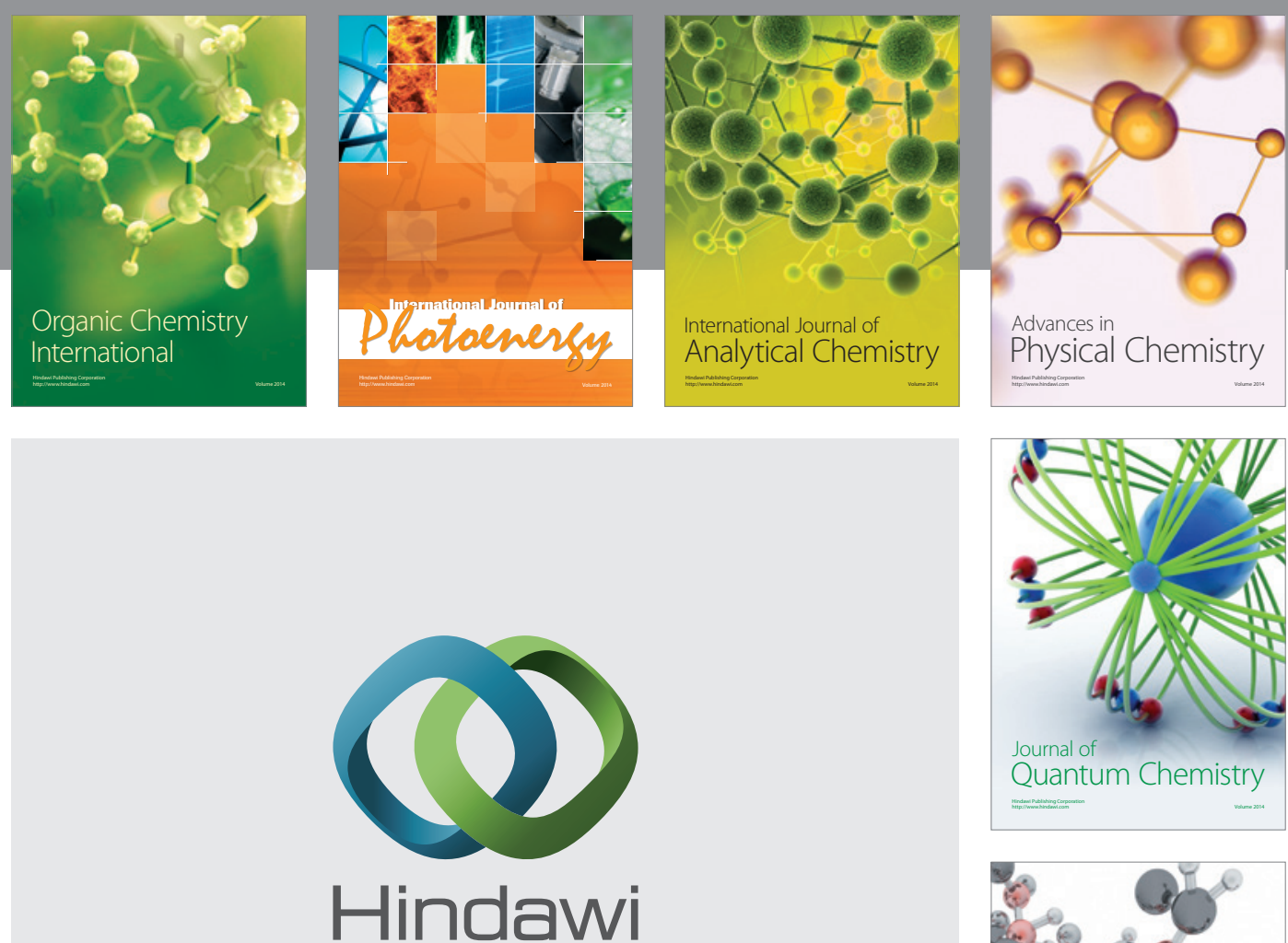

Submit your manuscripts at

http://www.hindawi.com

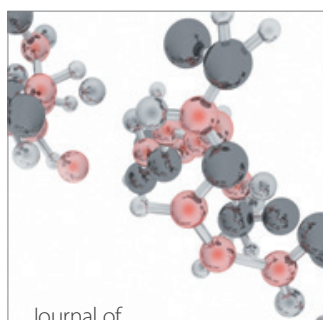

Analytical Methods

in Chemistry

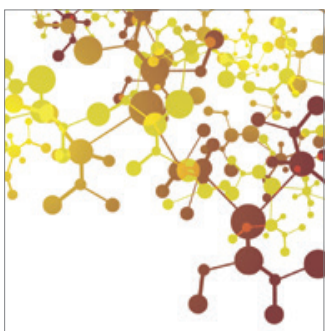

Journal of

Applied Chemistry

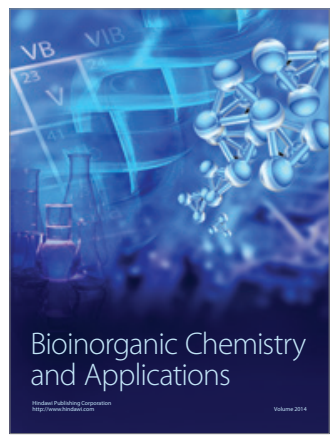

Inorganic Chemistry
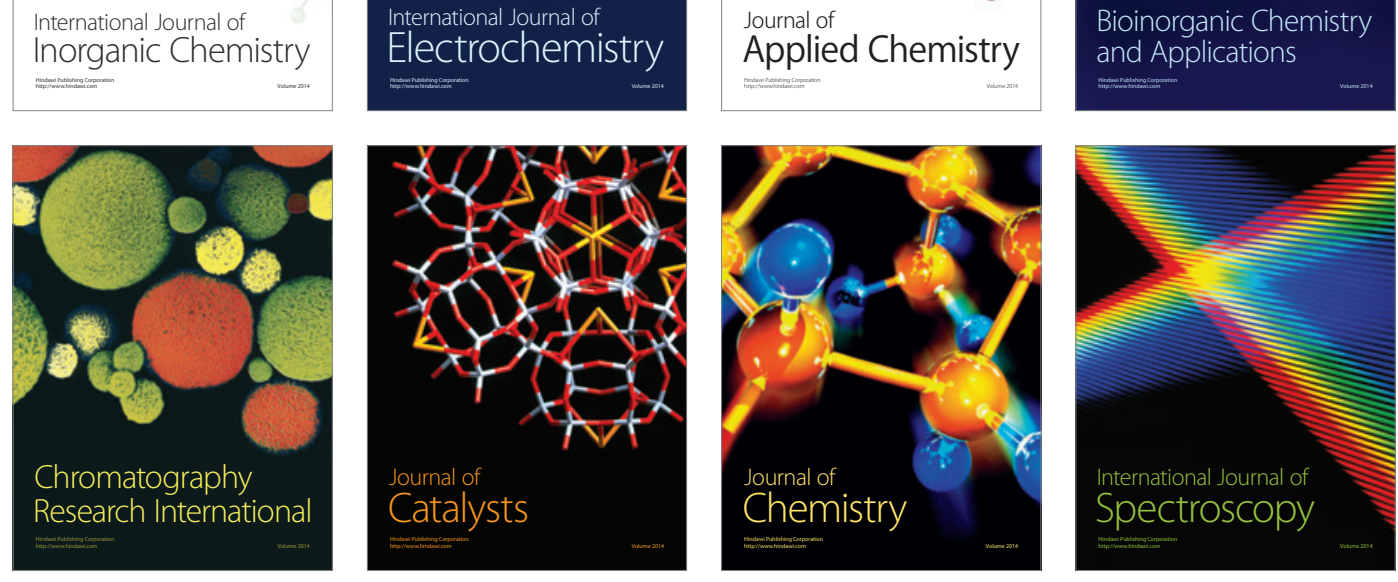